\title{
Observation of Drench of Porous Barrier Materials with Employment of the Conductivity Sensor
}

\author{
Pavel OTRISAL ${ }^{1,2}$, Vladimir OBSEL ${ }^{1,3}$, Simona BUNGAU ${ }^{4}$, Sarka HOSKOVA-MAYEROVA \\ ${ }^{1}$ Nuclear, Biological and Chemical Defence Institute, University of Defence in Brno, Address: Sidliste Vita Nejedleho, \\ 68203 Vyskov, Czech Republic \\ ${ }^{2}$ Faculty of the Physical Culture, Palacký University Olomouc, Address: Třida Miru 117, 77111 Olomouc, Czech \\ Republic \\ ${ }^{3}$ DEZA, Hochmanova 1, 62801 Brno, Czech Republic \\ ${ }^{4}$ Faculty of Medicine and Pharmacy, University of Oradea, Address: Sq. 1 Decembrie, 10, 410073, Oradea, Romania \\ ${ }^{5}$ Department of Mathematics and Physics, Faculty of Military Technology, University of Defence in Brno, Address: \\ Kounicova 65, 66210 Brno, Czech Republic
}

E-mails:1'pavel.otrisal@unob.cz; ${ }^{2}$ vobsel@seznam.cz;3 simonabungau@gmail.com;4 sarka.mayerova@unob.cz

\begin{abstract}
Nowadays, filtration barrier materials are more often used for providing with long-term protection of the Czech Armed Forces professionals and Fire Rescue Brigades specialists against the effects of toxic compounds. A comprehensive study provided authors with evaluation of their protective properties' qualitative changes in connection with knowledge development of possibilities of sensor technologies at this time. A solution usable for an electronic detection of the moment of water permeation or a liquid phase of other test chemicals (penetration) through construction materials of a filtration type or permeable barrier materials which are or perspectively can be used for protection against the effects of toxic compounds has been recently proposed. The aim of the solution is to replace a current used subjective way of the visual observation of water or other test chemicals penetration through textile materials used in anti-gas protection with the objective observation of the moment of test chemicals permeation (time of drench) with the help of a conductivity sensor with a possibility of an automatic record of the rate of penetration with the employment of the KONDUKTOTEST device.
\end{abstract}

KEY WORDS: conductivity sensor, barrier material, chemical warfare agent, drench, penetration

\section{Introduction}

Protection of military professionals and civilian firefighters against effects of toxic compounds is possible to understand as comprehensive problems coming within the ambit of a row of under interest areas of military, security and science [1-3]. Protection against effects of weapons of mass destruction and toxic industrial materials is a traditional and long-term crucial part of force protection in the area of military [4-7]. Specific tasks pointed to formation of conditions for deployed forces in the environment with chemical, radioactive and biological contamination quite unambiguously are a part of professional gesture of the Czech Armed Forces Chemicals Corps [8-11]. One of conditions of forces survival in areas contaminated with chemical, radioactive and biological agents is their provision with high quality individual protective equipment (IPE) that will be made of the first-rate barrier materials and, moreover, will meet a number of specific demands [12,13]. One of them is the resistance of IPE's barrier materials against permeation (penetration or drench), which should be relevantly investigated and evaluated. Requirements that are specified for the fulfillment of tasks in military operations are similarly applicable to the conditions of dealing with toxic leakage interventions for which the specialists of the chemical service of the Fire Rescue Service are primarily responsible [14-16].

It should be emphasized that a present way of porous barrier materials drench evaluation consists of a visual observation of the time of penetration of colored liquid (water or other liquid phase of the test chemical) through textile barrier materials with or without hydrophobic or oleophobic treatment. The main disadvantage of current procedure is the fact that the worker must be present at all time of testing and at regular intervals observe the reverse side of the sample of the tested material contaminated from the true side with a liquid phase of a test chemical [17,18]. Automatic penetration tracking can be done using either an on-line video recorder recording the change of color at the penetration point or detecting the moment (time) of detection with a suitable sensor, in this case conductivity.

${ }^{1}$ Corresponding author.

E-mail address: pavel.otrisal@unob.cz. 
This sensor will be in a close contact with the backside of the sample being tested. As the undeniable advantage can be considered the fact that the recordings obtained using the camcorder or obtained from the sensor behavior can be digitized and continuously monitored and evaluated even without the presence of the operator in real time and with a time delay in the same quality [19-21].

\section{The Survey of Current Knowledge}

At the present time, standard methodology of PROMOKAVOST is used in a branch of the anti-gas protection for evaluation of penetration of water, chemical warfare agents (CWA), or other toxic or aggressive liquids through porous barrier materials [22,23]. This methodology allows the visual observation of the liquid phase penetration of the colored test chemicals by 20 exposed sample of the tested material simultaneously with the MINITEST device (Figure 1). Textile materials from which permeable protective clothing is made are usually combined with hydrophobic and oleophobic treatments and should protect soldiers and firefighters not only against vapors and aerosols of volatile toxic substances but to some extent also against rain and penetration of small drops of CWA (to 20 $\mu$ l) [24-26]. The effectiveness of this protection is based on the PROMOKAVOST methodology for free-flowing drops of water, CWA or model test substances (test chemicals) with a similar surface tension (Table 1, Figure $1 \mathrm{a}, \mathrm{b}$ ).

Table 1.

Surface tension of water, CWA and selected test chemicals

\begin{tabular}{|c|c|c|c|}
\hline Test chemical & $\begin{array}{c}\text { Surface tension } \\
{[\mathbf{m N} \cdot \mathbf{m}-\mathbf{1}]}\end{array}$ & Test chemical & $\begin{array}{c}\text { Surface tension } \\
{[\mathbf{m N} \cdot \mathbf{m}-\mathbf{1}]}\end{array}$ \\
\hline Soman (GD) & 24,5 & Propanol & 23,7 \\
\hline Sulfur mustard (HD) & 42,9 & Nitrobenzene & 41,8 \\
\hline VX compound & 32,0 & Olive oil & 33,0 \\
\hline Acetic acid & 28,0 & Water & 72,8 \\
\hline
\end{tabular}

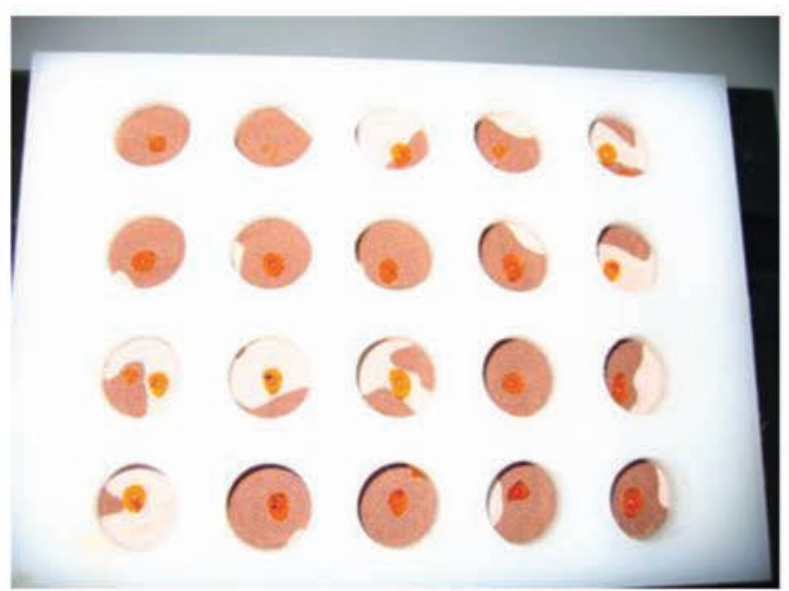

a)

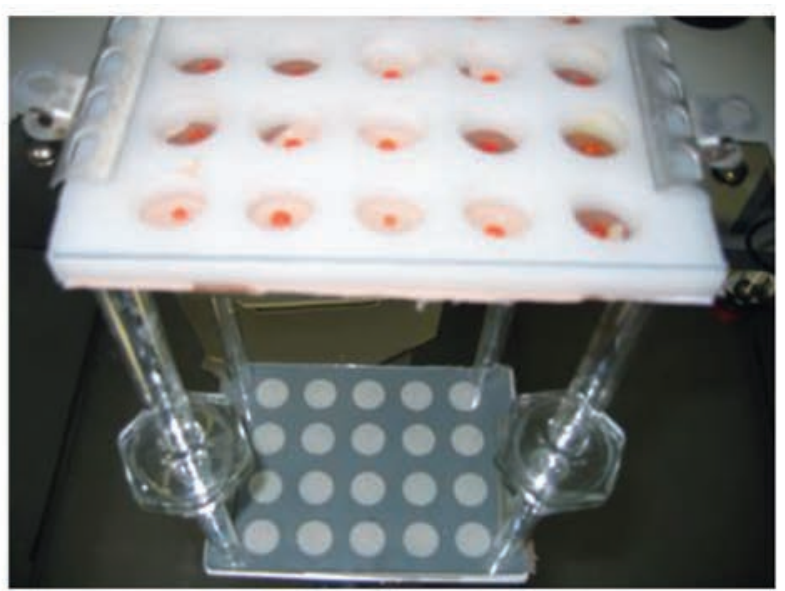

b)

Fig. 1. The way of textile sample with hydrophobic and oleophobic treatments contamination with the liquid phase of the test chemical (a) and the set ordering within observation of the contaminated sample from the back side (b).

For the above-mentioned reasons, an attempt was made to replace the visual observation of the liquid phase of the test chemical penetration by automatic monitoring the moment (time) of penetration by means of a suitable sensor. An original four place conductivity sensor was developed by two metallic ridges on a printed circuit board for this purpose (Figure 2). On the other hand, this sensor segment is provided with a surface heating from the resistance wire from another side (b). The surface heating allows either the setting of the desired temperature during testing or drying within at increased temperature. 

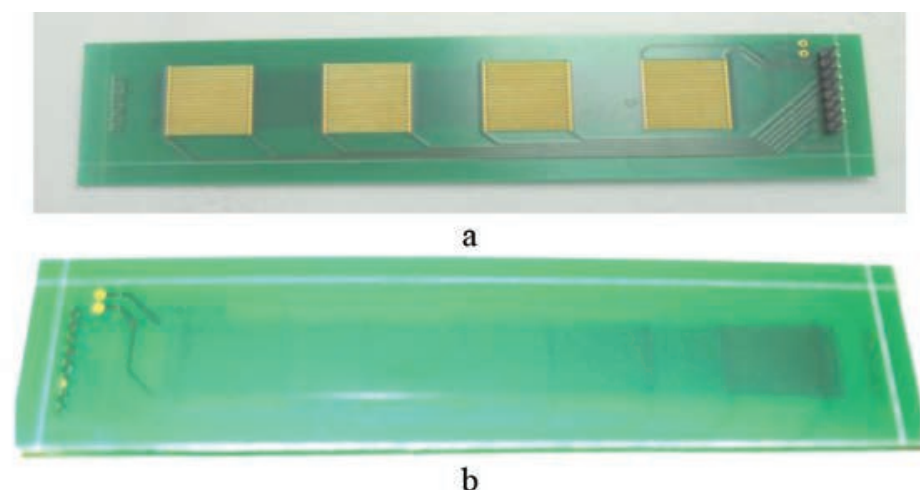

Fig. 2. Four place segment of the conductive sensor on the circuit board: $\mathrm{a}$ - front view with sensors, $\mathrm{b}$ - view from the back with heating.

This four-place sensor is possible to locate under a punched PVDF board of the MINITEST device with an underlaid textile tested material contaminated with drops of the test chemical with that is through a thin suction pad in a tight contact (Figure 3).

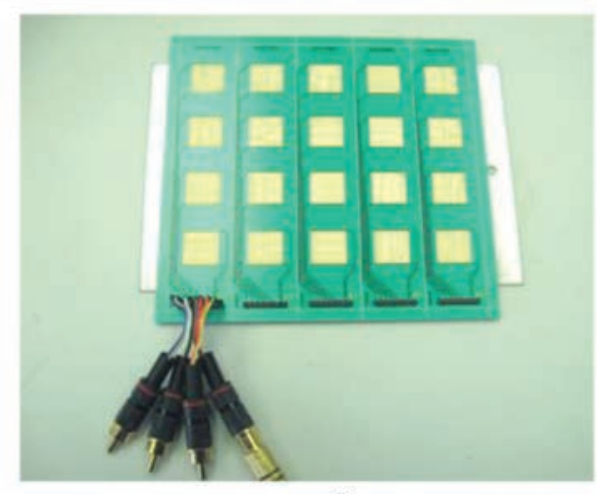

a

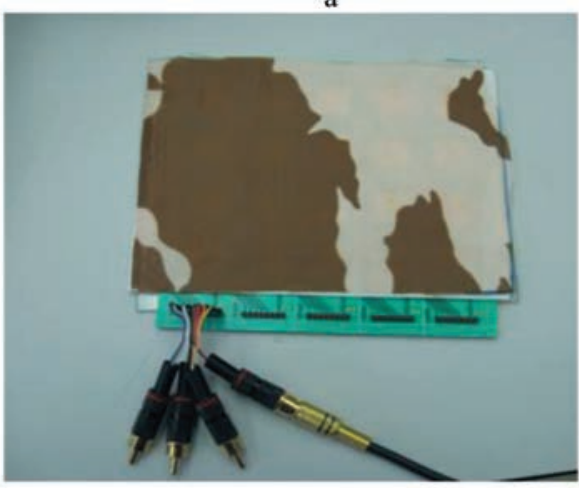

c

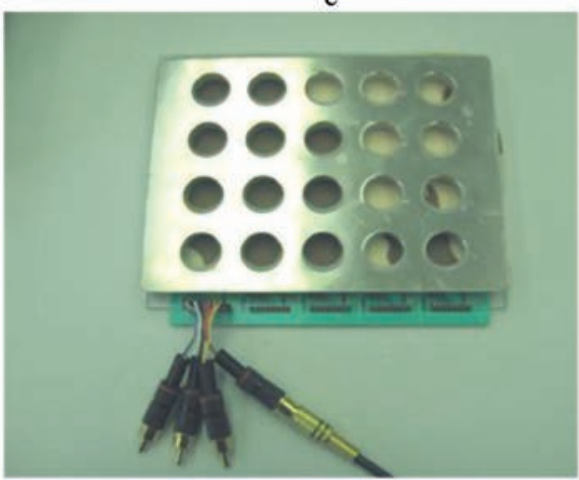

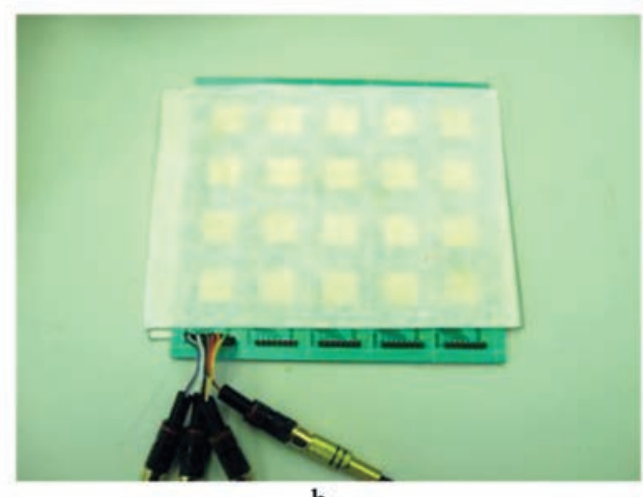

b

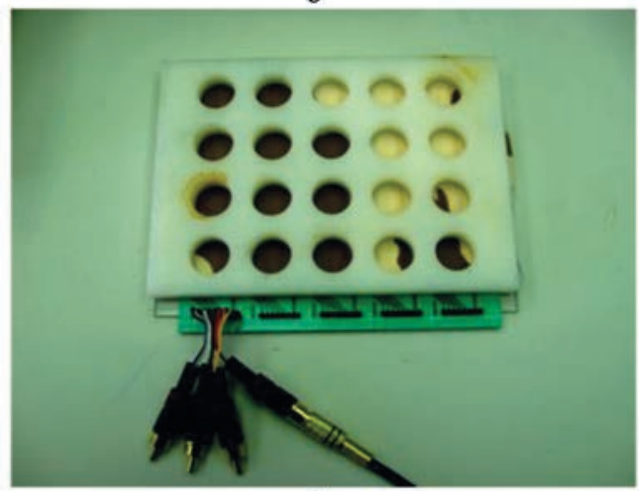

d

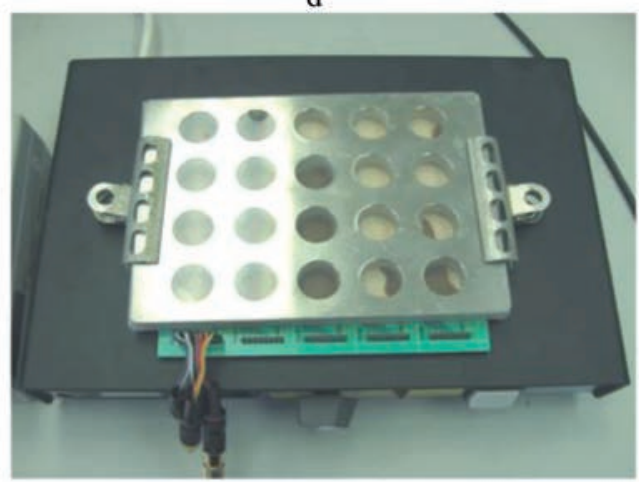

Fig. 3. Simple phases of the set for automatic observing of penetration of freely laying drops of water through textile materials by means of the conductive sensor. 
a - circuit board with 20 conductive sensors, b - sucking pad, c - sample of the tested material, d - punched PVDF board, e - covering glass board with laid stainless-steel punched mask $(2 \mathrm{~mm}), \mathrm{f}$ - set with clamps laid on thermostatic heated board

If we laid the punched PVDF board of the MINITEST device with five four place conductive sensors (Figure $3 \mathrm{a}, \mathrm{b})$ we can observe water penetration with the help of all twenty exposed places with gradual connecting of simple sections of the KONDUKTOTEST device.
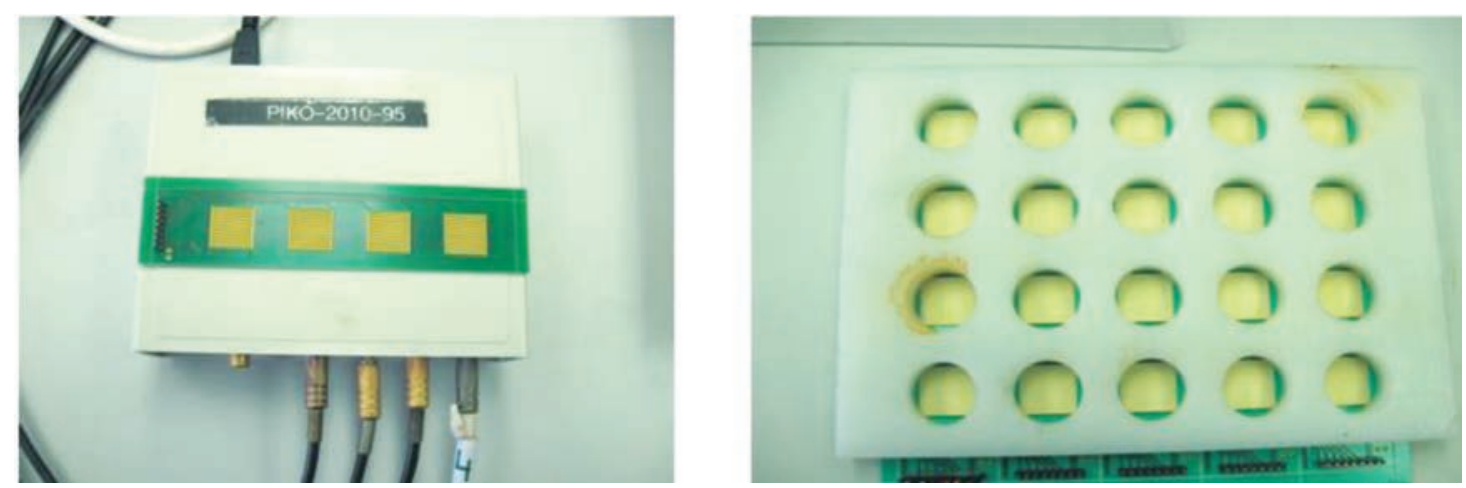

Fig. 4. Four place conductive sensor laid on a controlled unit of the KONDUKTOTEST device: a - location of five four place conductive sensors under the punched PVDF board of the MINITEST device.

Each of the four sensors is connected to one of measuring points of KONDUKTOTEST device to detect the time of free water droplet penetration through tested material. The principle is based on the rapid increase in sensor conductivity after wetting at the time of material penetration (material soaking). The current sensor can only detect penetration of water or other conductive liquids.

\section{Used Devices and Equipment}

The four-place conductivity sensor consists of a pair of conductive gold-plated cooper combs with 32 elements $(2 \times 16)$, dimension $17 \times 17 \mathrm{~mm}$, which are repeated four times on the printed circuit board. Through the dry sensor does not pass any current, however, when the water penetrates (best the conductivity standard) through the tested material, the sensor humidifies, and among combs a stream of tens till hundreds of microns starts passing. It reaches $300 \mu \mathrm{S}$ with the employment of a standard conductive solution of $\mathrm{KCl}$ in water $(10,000 \mu \mathrm{S} / \mathrm{cm})$. The conductivity is detected with the KONDUKTOTEST device. This system enables continual observation (monitoring) of a water penetration rate and its digitalization and subsequent elaboration and evaluation. Within evaluation of the time of drench it is only necessary to locate the sample of the tested material underlaid with the thin cotton paper and, moreover, on segments of conductive sensors in order to keep the whole set in the tight contact in the set of MINITEST device (Figure 2). After contamination of 4 or all 20 exposed places of the sample with drops of either salted water or the conductive standard, covering holes with the glass board, location of the set on thermostatic heated board and finally connection to the KONDUKTOTEST device it is possible to observe the penetration rate including a record and evaluation of results with the help of a computer and the standard software equipment (Figure 5)

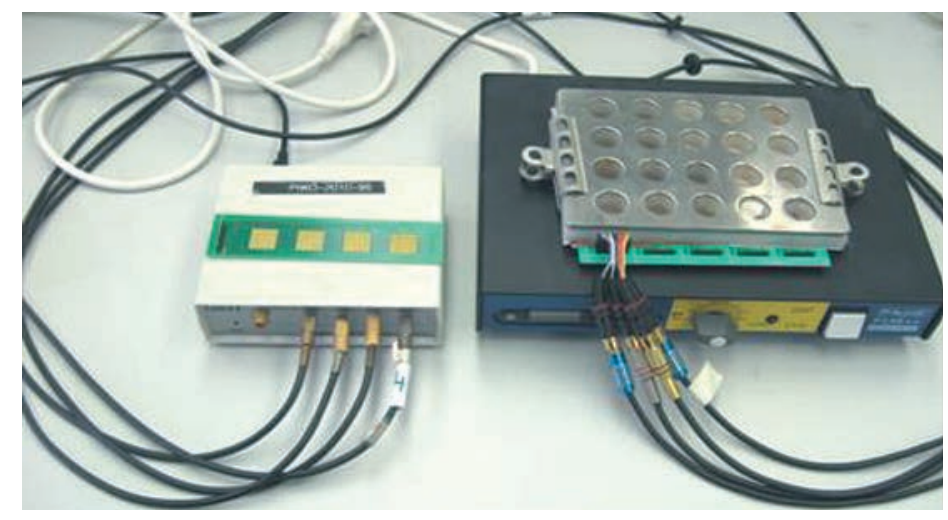

Fig. 5. Connection of conductive sensors located in the MINITEST device into the control unit of the KONDUKTOTEST device. 


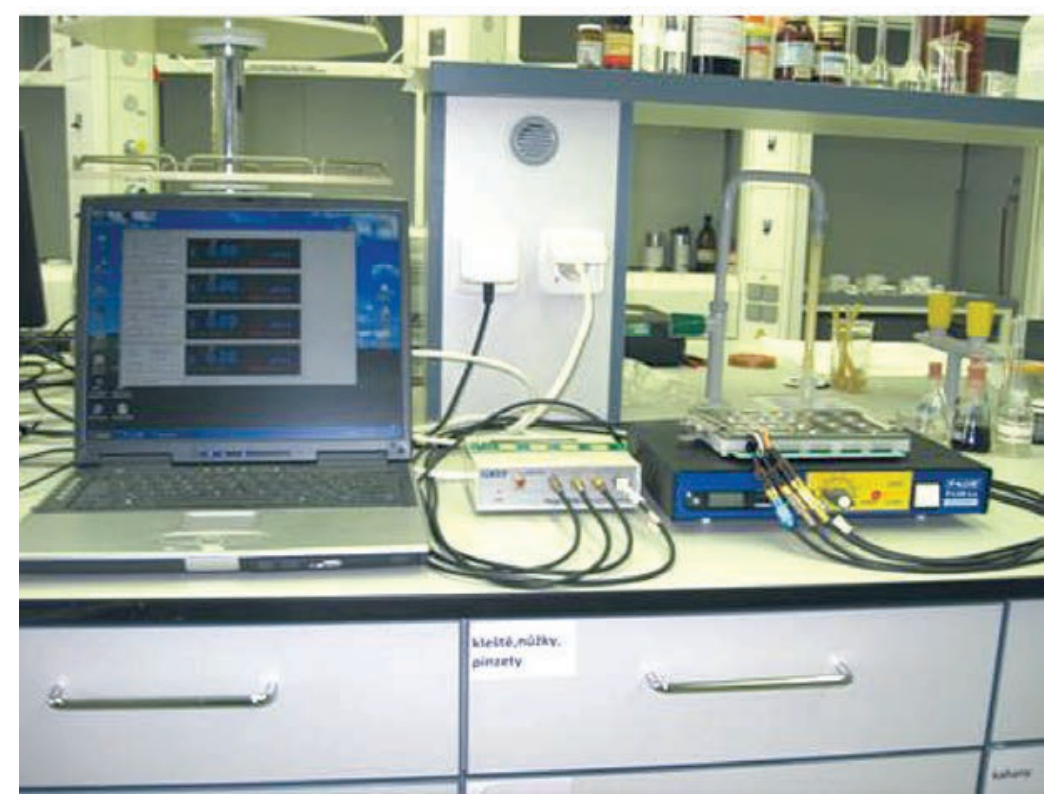

Fig. 6. The proposal of the device for automatic observation of freely lying drops of water penetration rate through textile materials with the help of the conductive sensor.

\section{Results and Discussion}

In the figure $7 \mathrm{a}$ there is the record of a measurement with the conductive sensor without tested material ((blind attempt), in the figure $7 \mathrm{~b}$ there is the record of the measurement within the dip of a soaked layer, in the figure 7c there is the record of the measurement within the dip of an unprepared tested polyester fabric underlaid with a suction pad and laid on the punched PVDF board. In the figure $7 \mathrm{~d}$ there is the record of the measurement similar as in the case of 7c, the punched PVDF board is, however, covered with glass and burdened with the stainless steel punched mask.

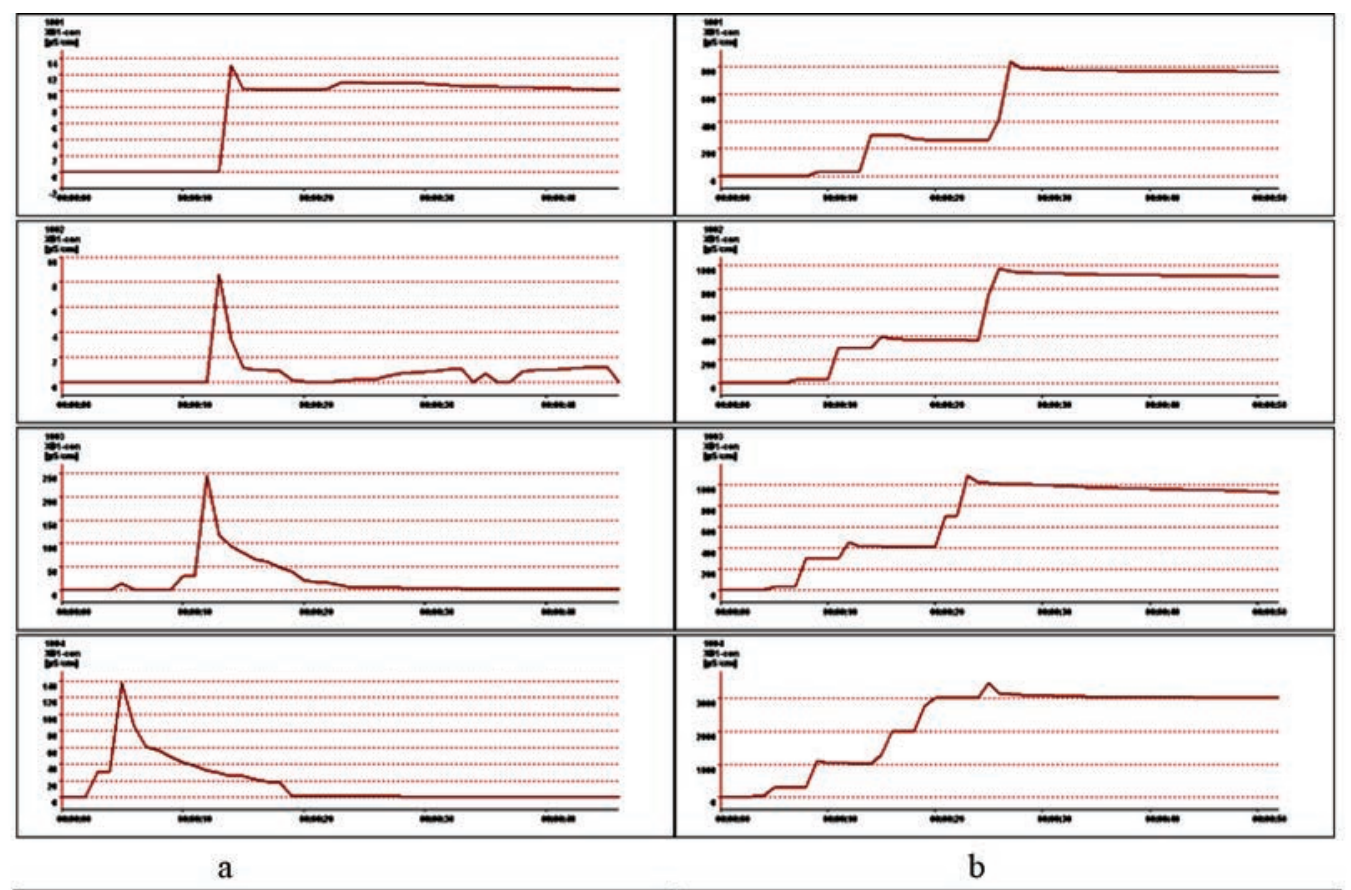




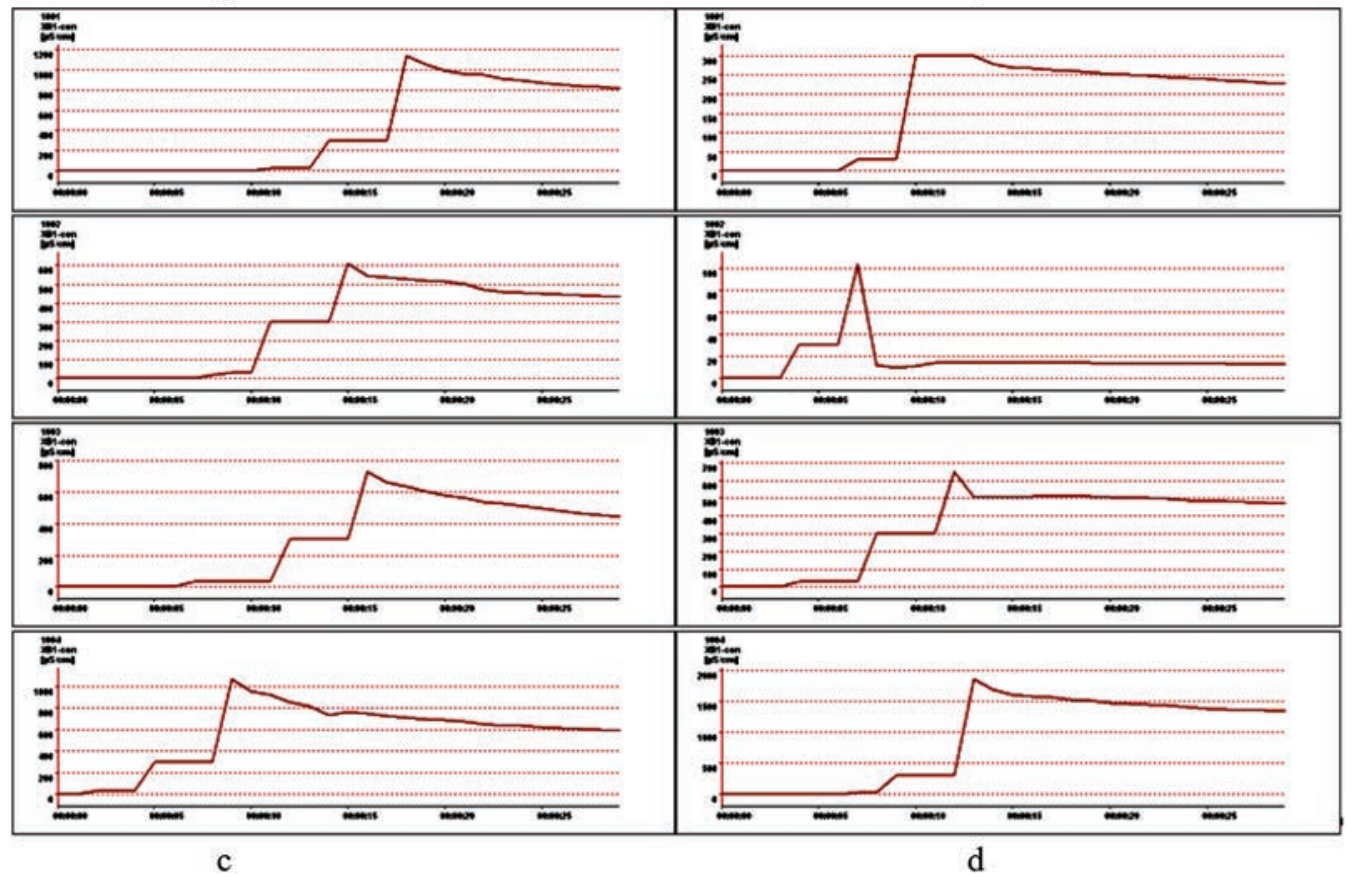

Fig. 7. Verification of a conductive sensor function:

a - blind attempt, b - only sucked pad, c - sucked pad covered with the tested material, $\mathrm{d}$ - the same as c, however, covered with glass and burdened with the stainless steel punched mask.

Humectation of the sensor is accompanied with significant increase of conductivity responding the moment of penetration of the liquid phase of test the chemical (in this case the standard conductivity standard) in all cases. The penetration rate of freely lying drop of water (conductivity standard) through the textile material without the hydrophobic modification is introduced in figure 8.
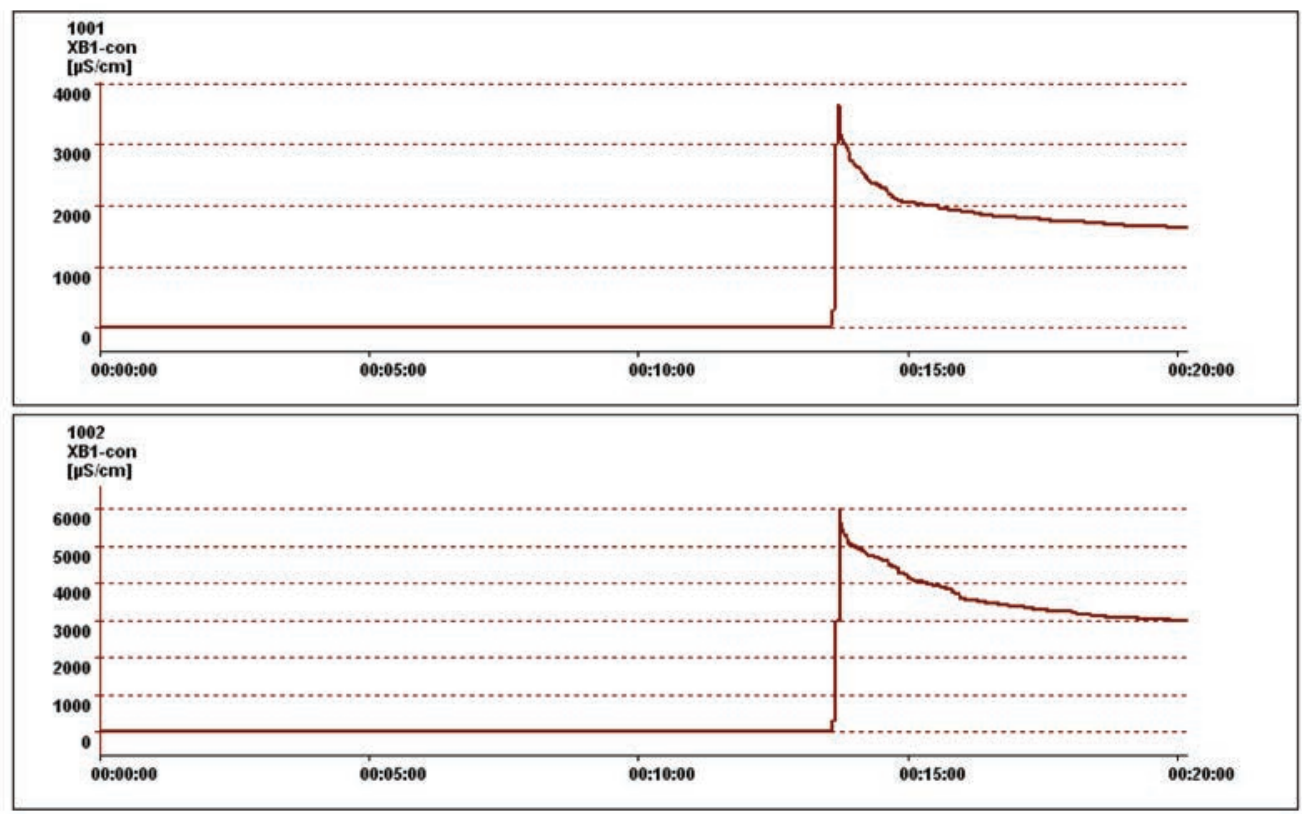


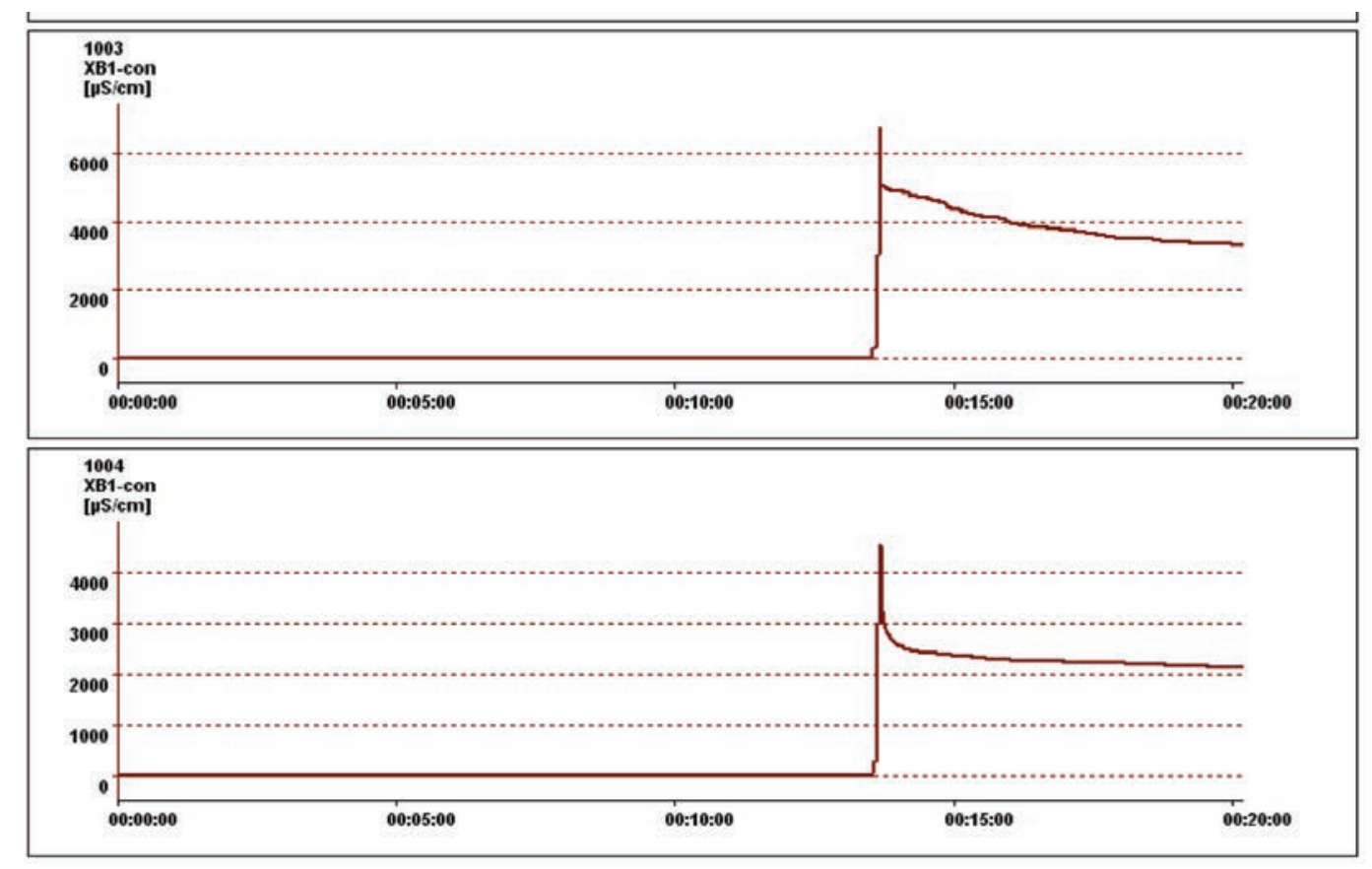

Fig. 8. Freely lying drop of water (the conductivity standard) penetration rate through the textile material without a hydrophobic modification.

\section{Proposal of Further Solution}

The proposed way of continual observation (monitoring) of lying water droplets penetration rate through textile materials using the comb conductivity detector can also be used principally for penetration of non-conductive liquids. It is only necessary to conform the construction to other conditions of the measurement. This one is going to be a subject of further study. It is supposed that the verification of the possibility of employment of this sensor or similar one even for other liquids on the principle of impedance or capacity will be performed.

\section{Conclusion}

Practical of continual observation (monitoring) of lying water droplets penetration rate through textile materials is realistic on the basis of the performed experiments. The result of the proposed solution is a functional device allowing for this purpose to use the existing KONDUKTOTEST and PROMOKAVOST methodologies. It has been unambiguously proved that a newly developed type of conductivity detector that can be incorporated into the measuring system and verified its function under realistic conditions is usable for the purposes of detecting permeability through barrier materials. After solving some sub-technical problems, it is possible to implement device in the GRYF HB, Ltd company which has collaborated on this solution, subsequently to realize and to implement it in practice. This device will make it possible to fundamentally innovate the current PROMOKAVOST methodology.

\section{Acknowledgements}

This work was conducted within the framework of the NBC Defence Institute of the University of Defence long-term intention of the organization development "Research on methods and technologies of protection against the effects of weapons of mass destruction and industrial hazardous substances" (PROTECT), the project "Development of capabilities and sustainability of logistic support systems" ROZVOLOG, DZRO K-109 and the project for development of basic and applied research developed in the long term by the departments of theoretical and applied bases FMT VÝZKUMFVT, DZRO K-217 supported by the Czech Republic MoD.

\section{References}

1. Hoskova-Mayerova S. Education and Training in Crisis Management, The European Proceedings of Social \& Behavioural Sciences EpSBS, Volume XVI, (2016) p. 849-856. doi:10.15405/epsbs.2016.11.87.

2. Bekešiene, S., Kleiza, V., Tamuliene, J. Theoretical study on the molecular structures of nitrophenols and trinitrophenols (2008) Proceedings of the 3rd International Workshop - Intelligent Technologies in Logistics and 
Mechatronics Systems, ITELMS 2008, pp. 7-12.

3. Bekešiene, S., Kleiza, V., Malovikas, A. Military specialist preparation features in nowadays environment (2009) Intelligent Technologies in Logistics and Mechatronics Systems, ITELMS 2009 - Proceedings of the 4th International Conference, pp. 158-163.

4. Kellnerová, E., Binková, K., Hošková-Mayerová, Š. Assessment of the efficiency of respiratory protection devices against lead oxide nanoparticles. Models and Theories in Social Systems. Studies in Systems, Decision and Control 179, 2019, p. 257-272. Springer, doi: 10.1007/978-3-030-00084-4_14.

5. Vališ, D., Žák, L. Hasilová, K., Vintr, Z. Applying Regression Diagnostics for Identifying Non-standard Behaviour of a Technical System. In: 2017 International Conference on Military Technologies (ICMT). Piscataway, NJ 08854-4141 USA: Institute of Electrical and Electronics Engineers Inc., 2017, p. 142-148

6. Otrisal, P., Obsel, V., Florus, S., Bungau, C., Aleya, L., Bungau, S. Protecting emergency workers and armed forces from volatile toxic compounds: applicability of reversible conductive polymer-based sensors in barrier materials, Science of the Total Environment, 2019, 694, 133736. https://doi.org/10.1016/j.scitotenv.2019.133736

7. Talhofer, V., Hošková-Mayerová, Š. Method of Selecting a Decontamination Site Deployment for Chemical Accident Consequences Elimination: Application of Multi-Criterial Analysis. ISPRS Int. J. Geo-Inf., 2019, 8(4), p. 22. doi:10.3390/ijgi8040171

8. Otřísal, P. Decontamination Modules Formed by the Czech Armed Forces Chemical Corps. Croatian Journal of Education-Hrvatski Casopis za Odgoj i obrazovanje, 14(1), 2012, p. 123-127.

9. Štěpánek, B., Otřísal, P. The Development and Establishment Process of Centres of Excellence in North Atlantic Organization. Croatian Journal of Education-Hrvatski Casopis za Odgoj i obrazovanje, 14(1), 2012, p. 169-174.

10. Otrisal, P., Melicharik, Z., Svorc, L., Bungau, S., Virca, I., Barsan, G., Mosteanu, D. Testing methods of assessment for the chemical resistance of insulating materials against the effect of selected acids, Materiale Plastice, 55(4), 2018, p. 545-551.

11. Plzakova, L., Krocova, Z., Kubelkova, K., Macela, A. Entry of Francisella tularensis into murine B cells: The role of B cell receptors and complement receptors. PLoS ONE, 10(7), 2015. Article Number: e0132571.

12. Vališ, D., Nováček, O., Hasilová, K., Leuchter, J. Modelling of degradation and a soft failure moment during the operation of a supercapacitor applying selected diffusion processes. Engineering Failure Analysis, 2017 , vol. 82, no. 04/2017, p. 582.

13. Procházka, J., Procházková, J. Problems of mobile risks in territory, Safety and Reliability - Safe Societies in a Changing World, Taylor \& Francis Group, p. 1783, London 2018.

14. Otřrísal, P. Czech Armed Forces Chemical Corps tasks set in operational doctrine of "Land Forces in operations". (in Czech). In Sborník konference „Aktuální problémy ochrany vojsk a obyvatelstva před účinky ZHN a průmyslových nebezpečných látek - 2011“. Editoři P.

15. Otřísal, P. Czech Armed Forces Chemical Corps tasks set in operational doctrine of "Land Forces in operations". (in Czech). In Sborník konference „Aktuální problémy ochrany vojsk a obyvatelstva před účinky ZHN a průmyslových nebezpečných látek - 2011“. Editoři P. Otř́sal, S. Florus. [CD-ROM]. Brno : University of Defence, 19.-20.10.2011 p. 1-11. ISBN 978-80-7231-834-6.

16. Svarcova, I., Hoskova-Mayerova S., Navratil, J., Crisis Management and Education in Health, The European Proceedings of Social \& Behavioural Sciences EpSBS, Volume XVI, 2016, p. 255-261. doi:10.15405/ epsbs.2016.11.26.

17. Prikryl, R., Otrisal, P., Obsel, V., Svorc, L., Karkalic, R., Buk, J. Protective Properties of a Microstructure Composed of Barrier Nanostructured Organics and SiOx Layers Deposited on a Polymer Matrix. Nanomaterials, 8(9), 2018, p. 679. https://doi.org/10.3390/nano8090679.

18. Florus, S., Otřísal, P. Selected methods of study of chemical resistance of insulation protective films for chemical warfare agents. Chem. Listy, 108(9), 2014, p. 838-842.

19. Collective. Pub-31-10-01 Land Forces in Operations. (in Czech) Vyškov : Department of Doctrine, Military Academy, 2011. $294 \mathrm{p}$.

20. Vševojsk-2-6. Chemical support in the Czech Armed Forces (in Czech). 1 st ed. Praha : Ministry of Defence, 2008. 109 p.

21. Obšel, V., Otřísal, P., Florus, S. Methodology of PROMOKAVOST for evaluation of drench ability and quality of hydrophobic and oleo phobic adjustment of textile materials against drops of water, CWAs of other toxic liquids with the possibility of quick statistic evaluation of achieved results. (in Czech). [Methodology for the stationary laboratory]. Vyškov : NBC Defence Institute, 2016. 20 p.

22. Otř́śsal, P., Florus, S. Current and perspectives in personal and collective protection against effects of toxic compounds. Chem. Listy, 108(12), 2014, p. 1168-1171.

23. Procházka, J. Procházková, D. Drinking water supply failure, Safety and Reliability - Theory and Applications, 
Taylor \& Francis Group, p. 2235, London 2017, ESREL 2017.

24. Otrisal, P., Obsel, V., Buk, J., Svorc, L. Preparation of Filtration Sorptive Materials from Nanofibers, Bicofibers, and Textile Adsorbents without Binders Employment. Nanomaterials, 8(8), 2018, p. 564. https://doi.org/10.3390/ nano8080564.

25. Hošková-Mayerová, Š. Emergency assessment in case of hazardous substance leakage at Czech Republic freight rail transport in 2008-2016. In: Safety and Reliability - Safe Societies in a Changing World, Proceedings of ESREL 2018, London: CRC Press, 2018, p. 1381-1386, doi:: 10.1201/9781351174664-174.

26. Otř́sal, P., Hošková-Mayerová, Š. Selected Aspects of Barrier Materials Assessment as a Part of the Reaction on Threats and Risks Connected with CBRN Problems. Decision Making in Social Sciences: Between Traditions and Innovations 247. Ed. Kacprzyk, J., Springer, 2020, p. 531-543.doi: 10.1007/978-3-030-30659-5_32. 